\title{
Hyponatraemia in Community Acquired Bacterial and Tubercular Meningitis in Hospital Admitted Adult Patients
}

\author{
POLY SENGUPTA, ${ }^{1}$ MD. ROUSHAN ALI,${ }^{2}$ FAZLE RABBI MOHAMMED, ${ }^{3}$ RAMA BISWAS, ${ }^{1}$ MAMUNUR RASHID, ${ }^{4}$ \\ SHAMSHUN NAHAR ${ }^{5}$
}

\begin{abstract}
:
Background: Bacterial and Tubercular Meningitis is a life-threatening disease. Hyponatraemia in bacterial and tubercular meningitis is a known complication with unknown true prevalence and clinical importance. This study was conducted to find out how commonly hyponatraemia occurs in community acquired bacterial and tubercular meningitis, to evaluate its severity, to see the pattern of presentation and to observe the level of consciousness.

Materials and Methods: It was a descriptive cross sectional study performed in 30 admitted patients with clinically diagnosed bacterial and tubercular meningitis in medicine wards of Medical College for Women \& Hospital (MCWH) and Dhaka Medical College \& Hospital (DMCH) since August 2009 to March 2010. Serum electrolyte and level of consciousness on admission was recorded in all patients.

Results: Twenty Nine patients (96.7\%) with meningitis had hyponatraemia, serum sodium level ranged from I I 5 $138 \mathrm{mmol} / \mathrm{l}$; mean sodium level is $128.57 \pm 5.56 \mathrm{SD}$ mmol/L. Serum sodium level was mild (>/25-/ $35 \mathrm{mmol} / \mathrm{L})$ in 20 (66.7\%) patients with meningitis and moderate (I I $0-125 \mathrm{mmol} / \mathrm{L})$ in $9(30 \%)$ and severe (<I $10 \mathrm{mmol} / \mathrm{L})$ in I (3.3\%) patient. GCS ranged from 8 to 14 , mean II.56 I.40 SD in day I. In tubercular meningitis $(n=8)$ and bacterial meningitis $(n=22)$ serum sodium level was I 28.63 \pm 7.44 and I $28.55 \pm 4.93$ while mean GCS was I I.38 \pm 2.13 and II.95 1.40 respectively on the day of admission.

Conclusion: Although the true prevalence, severity and clinical importance of hyponatraemia in bacterial meningitis are unknown, its presence may influence the outcome in such patients depending on severity. So knowledge about its prevalence and severity will guide physicians to take decisions about its management.
\end{abstract}

Key Words: Hyponatraemia, Meningitis, Adults

\section{Introduction:}

Bacterial meningitis is an acute purulent infection within the subarachnoid space. Acute bacterial meningitis remains a major cause of death and long term neurological sequelae worldwide. ${ }^{1}$ The organism most commonly responsible for community acquired bacterial meningitis is Streptococcus pneumoniae (50\%), Neisseria meningitides (25\%), Group B streptococcus $(10 \%)$ and Listeria monocytogens $(10 \%)$ Haemophilus influenza type $\mathrm{b}(<10 \%))^{1,2}$ Tuberculosis involves the central nervous system (CNS) in approximately $10 \%$ of patients, with tubercular meningitis (TBM) as the

1. Specialist of Medicine, Square Hospital Ltd. Dhaka, Bangladesh.

2. Professor and Head, Dept. of Medicine, Medical College for Women and Hospital, Dhaka, Bangladesh.

3. Specialist of Respiratory Medicine, Square Hospital Ltd, Dhaka, Bangladesh.

4. Senior Lecturer, AIMST, Malaysia.

5. hesis part student, BSMMU, Dhaka, Bangladesh.

Correspondence: Dr. Poly Sengupta. Specialist of Medicine, Square Hospital Ltd. 18/F Bir Uttam Qazi Nuruzzaman Sarak (West Panthapath), Dhaka - 1205, Bangladesh. E mail: polysg39@yahoo.com,poly.sg2010@gmail.com most common presentation. ${ }^{1}$ Hyponatraemia in adults with community acquired bacterial meningitis has been described as a complication although its true prevalence and clinical importance are unknown. ${ }^{3}$ Patients with bacterial meningitis are at increased risk of developing acute hyponatraemia, although most cases are mild. ${ }^{4}$ Hyponatraemia has been reported in up to one third of patients with intracranial disease and has frequently been associated with tubercular meningitis. ${ }^{5,6,7}$ Hyponatraemia is not documented in aseptic or viral meningitis which is usually self limiting and has a very low mortality. ${ }^{1,8}$ The exact mechanism of hyponatraemia in bacterial meningitis is unknown but it is thought that it may be a result of cerebral salt wasting, the syndrome of inappropriate antidiuretic hormone secretion or exacerbation by aggressive fluid resuscitation. ${ }^{4}$ A number of studies in recent years have shown that hyponatraemia in many patients with intracranial disease may actually caused by cerebral salt wasting, in which a renal loss of sodium leads to hyponatraemia and a decrease in extracellular fluid volume. 5,9 The purpose of this study was therefore to find out how commonly hyponatraemia occurs in community acquired bacterial and tubercular meningitis, to evaluate its severity, 
to see the pattern of presentation in such patients, to observe the level of consciousness.

\section{Materials and methods:}

It was a descriptive cross sectional study. This study was carried out in 30 hospital admitted patients with clinically diagnosed bacterial and tubercular meningitis ( 22 bacterial and 8 tubercular) in medicine wards of Medical College for Women \& Hospital (MCWH) and Dhaka Medical College \& Hospital (DMCH) since August 2009 to March 2010. Initial study population was 42 . Twelve patients were excluded from the study due to not fulfilling the inclusion criteria. Patients of encephalopathy due to metabolic and endocrine causes \& other causes were excluded from this study. Ten patients were collected from MCWH and 20 patients were collected from DMCH. Information from all these patients was taken using case record form, symptoms and signs on admission, blood and cerebrospinal fluid (CSF) results, radiological examination and complications during admission were recorded. Serum electrolyte level was investigated on admission. Hyponatraemia was defined as serum sodium level below $135 \mathrm{mmol} / \mathrm{L}$ (mild > 125-135, moderate 110-125, severe $<110 \mathrm{mmol} / \mathrm{L}$ ). Informed consent was taken from the patient or from the attendant of the patient for participation in the study. SPSS was used for data management and statistical analysis.

\section{Result:}

In this study total 30 patients were included. Of them 18 were male and 12 were female with a ratio of 1: 0.67. Mean age was $29 \pm 15.27$ SD years. All 30 (100\%) patients had headache, altered consciousness, fever. Duration of fever ranged from 7 to 60 days; mean duration was $16.43 \pm 10.07$ SD days. Among the patients $2(6.7 \%)$ had history of seizure.

\section{Table I}

Clinical signs of patients with meningitis with hyponatraemia $(N=30)$

\begin{tabular}{lcc}
\hline Clinical signs & Present & Absent \\
\hline Neck rigidity & $29(96.7 \%)$ & $1(3.3 \%)$ \\
Kernig's sign & $29(96.7 \%)$ & $1(3.3 \%)$ \\
Brudginski's sign & $2(6.7 \%)$ & $28(93.3 \%)$ \\
Plantar extensor response & $4(13.3 \%)$ & $26(86.7 \%)$ \\
Papilloedema & $6(20 \%)$ & $24(80 \%)$ \\
\hline
\end{tabular}

Most of the patients had Neck rigidity and Kernig's sign (96.7\%).

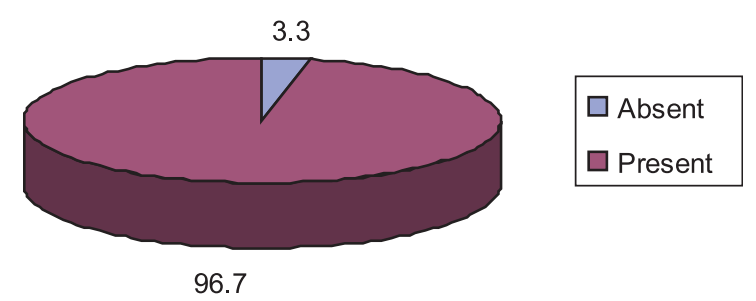

Fig.-1: Percentage of Hyponatraemia in Meningitis

Hyponatraemia was present in $29(96.7 \%)$ patients (Fig 1)

Table II

Severity of hyponatraemia in patients with meningitis $(N=30)$

\begin{tabular}{lc}
\hline Severity & Percentage of patients \\
\hline Severe $(<110 \mathrm{mmol} / \mathrm{L})$ & $1(3.3 \%)$ \\
Moderate $(110-125 \mathrm{mmol} / \mathrm{L})$ & $9(30.0 \%)$ \\
Mild $(>125-135 \mathrm{mmol} / \mathrm{L})$ & $20(66.7 \%)$ \\
\hline
\end{tabular}

Most of the patients had mild hyponatraemia (66.7\%).

Mean serum potassium, chloride, bicarbonate level was $4.01 \pm 0.53 \mathrm{SD} \mathrm{mmol} / \mathrm{L} 94.41 \pm 16.87 \mathrm{SD} \mathrm{mmol} / \mathrm{L}$ and $23.69 \pm 2.40$ $\mathrm{SD} \mathrm{mmol} / \mathrm{L}$ respectively.

Table III

Serum sodium and corresponding GCS on the day of admission

\begin{tabular}{lcc}
\hline Diagnosis & GCS $($ mean \pm SD) & Serum sodium $(\mathrm{mmol} / \mathrm{l})$ \\
\hline Meningitis $(\mathrm{N}=30)$ & $11.56 \pm 1.40$ & $128.57 \pm 5.56$ \\
TB Meningitis $(\mathrm{n}=8)$ & $11.38 \pm 2.13$ & $128.63 \pm 7.44$ \\
Bacterial $(\mathrm{n}=22)$ & $11.95 \pm 1.40$ & $128.55 \pm 4.93$ \\
\hline
\end{tabular}

In both tubercular and bacterial meningitis, mean GCS was 11 and mean serum sodium was 128 .

Table IV

Indexes of CSF inflammation

\begin{tabular}{lcccc}
\hline CSF & Mean & Std. Deviation & Minimum & Maximum \\
\hline Cell count $(\mathrm{cmm})$ & 207.20 & \pm 521.13 & 4.00 & 2800.00 \\
Glucose $(\mathrm{mg} / \mathrm{dl})$ & 51.76 & \pm 16.24 & 30.00 & 89.00 \\
Protein $(\mathrm{g} / \mathrm{L})$ & 1.17 & \pm 0.43 & 0.37 & 2.04 \\
\hline
\end{tabular}

CSF study revealed mean cell count was $207 \pm 521.13 \mathrm{SD} / \mathrm{cmm}$. Mean CSF glucose was 51.76 \pm 16.24 SD mg/dl. Mean CSF 
protein was $1.17 \pm 0.43 \mathrm{SD}$ g/L. (Table IV) CSF Gram staining was positive in $6(20 \%)$. Among the positive cases gram negative diplococci was found in 4 patients and gram positive cocci was found in 2 patients. CSF culture was found positive in $2(6.7 \%)$. Both culture reports were positive for Neisseria meningitides.

\section{Discussion:}

This study was carried out in 30 hospital admitted patients with clinically diagnosed bacterial and tubercular meningitis ( 22 bacterial and 8 tubercular) in medicine wards of Medical College for Women \& Hospital (MCWH) and Dhaka Medical College \& Hospital (DMCH). Initial study population was 42. Twelve patients were excluded from the study due to not fulfilling the inclusion criteria, refused to sign consent form, could not afford investigations. ten patients were collected from MCWH and 20 patients were collected from DMCH. This study was conducted to find out how commonly hyponatraemia occurs in community acquired bacterial and tubercular meningitis in adults, to describe the severity of hyponatraemia in these patients, to observe the pattern of presentation of meningitis and level of consciousness among these patients.

In this study age of patients ranged from 14 to 75 years, mean age was $29 \pm 15.27$ SD years. Among 30 patients with meningitis $18(60 \%)$ were male and $12(40 \%)$ were female. Durand ML et al observed that age of patients ranged from 16 to $88 .{ }^{10}$ Among the patients GCS ranged from 8 to 14 , mean $11.56 \pm 1.40 \mathrm{SD}$ in day 1 . In Van de beek et al study a score of less than 10 on the Glasgow Coma Scale, were present in 313 of 696 episodes (45\%). ${ }^{11}$ Brouwer MC observed $157 / 208(76 \%)$ cases of meningitis had GCS score $<14 .^{3}$

Hyponatraemia in adults with community acquired bacterial meningitis is associated with a longer duration of symptoms, a lower CSF white cell count and a lower level of CSF protein. This is most probably because hyponatraemia needs time to develop, and is therefore more often found in patients with a less severe degree of inflammation. ${ }^{3,4}$ CSF results in our study revealed mean cell count was $207 \pm 521.13 \mathrm{SD} / \mathrm{cmm}$. Mean CSF protein was $1.17 \pm 0.43 \mathrm{SD}$ g/L. An exceptionally high rate of hyponatraemia in adults with meningitis due to L. monocytogenes $(73 \%)$ was found in a study. Comparable high rates of hyponatraemia have also been described in tubercular and Group A streptococcal meningitis. ${ }^{3,11,12}$ Hyponatraemia has been reported in up to one third of patients with intracranial disease and has frequently been associated with tubercular meningitis, often complicated by hydrocephalus. ${ }^{12}$ CSF Gram staining in our study was positive in $6(20 \%)$. Among the positive cases gram negative diplococci was found in 4 patients and gram positive cocci was found in 2 patients. CSF culture was found positive in 2 $(6.7 \%)$. Both culture reports were positive for Neisseria meningitides.

Hyponatraemia is a common and often considered as a benign complication in adults with bacterial meningitis. Moderate hyponatraemia in bacterial meningitis is found self limiting and regular checks of serum sodium is usually sufficient in most cases. ${ }^{3,4}$ In this study, 29 (96.7\%) patients with meningitis had hyponatraemia and in 1(3.3\%), hyponatraemia was absent. In one study hyponatraemia $(<135 \mathrm{mmol} / \mathrm{L})$ was seen in 208/685 (30\%) and hyponatraemia developed during admission in an additional 53 episodes. ${ }^{3}$ In Singh BS et al study hyponatraemia was detected in $65 \%$ of cases on admission, $47 \%$ on day 3 and in $30.8 \%$ on day 10. ${ }^{13}$ In Brower MC et al study sodium levels were determined at admission in $685 / 696$ episodes of bacterial meningitis (98\%). Hyponatraemia ( $<135 \mathrm{mmol} / \mathrm{L}$ ) was seen in 208/685 $(30 \%) .{ }^{3}$ In our study serum sodium level ranged from 115 $138 \mathrm{mmol} / \mathrm{l}$; mean sodium level is $128.57 \pm 5.56 \mathrm{SD} \mathrm{mmol} / \mathrm{L}$. In TB Meningitis $(n=8)$ and bacterial meningitis $(n=22)$ serum sodium level was $128.63 \pm 7.44$ and $128.55 \pm 4.93$ while mean GCS was $11.38 \pm 2.13$ and $11.95 \pm 1.40$ respectively on the day of admission. In Singh BS et al study of patients with tubercular meningitis, mean serum sodium level was (130.7 \pm $6.26 \mathrm{mEq} / \mathrm{L}) .{ }^{13}$ Patients with bacterial meningitis are at increased risk of developing acute hyponatraemia, although most cases are mild. ${ }^{4}$ In this study serum sodium level was mild ( $>125-135 \mathrm{mmol} / \mathrm{L})$ in $20(66.7 \%)$ patients with meningitis and moderate $(110-125 \mathrm{mmol} / \mathrm{L})$ in $9(30 \%)$ and severe $(<110$ $\mathrm{mmol} / \mathrm{L})$ in $1(3.3 \%)$ patient. In Brower MC et al study hyponatraemia was classified as severe $(<110 \mathrm{mmol} / \mathrm{L})$ in 38 $(6 \%) .{ }^{3}$ There are no clinical data on fluid management for hyponatraemia in adults with bacterial meningitis. A recent Cochcrain review on this topic in children with bacterial meningitis identified six clinical trials, but only three met inclusion criteria. Two of these trials also showed no effect of fluid resuscitation on serum sodium level after 24 and 72 hours in settings with high mortality rates, and where patients present late. However, where children present early and mortality rates are lower, there is sufficient evidence to guide practice. $^{14}$

The aetiologic mechanism of hyponatraemia in bacterial meningitis is unclear. It may result from the syndrome of inappropriate antidiuretic hormone secretion, the cerebral salt wasting (CSW) syndrome, or aggressive fluid resuscitation. ${ }^{3,4,15}$ Hyponatraemia associating with tubercular meningitis has three main differential diagnosis: adrenal insufficiency, inappropriate secretion of antidiuretic hormone and cerebral salt wasting. Patients with hyponatraemia due to tuberculosis have shown variable 
responses to water loading in few small studies, ranging from persistent antidiuresis to a normal diuresis. Although tuberculosis is considered a cause of the syndrome of inappropriate antidiuretic hormone secretion (SIADH), circulating vasopressin has been documented in only a few cases. ${ }^{15,16,17,18}$ SIADH is a volume-expanded state because of antidiuretic hormone-mediated renal water retention. CSW is characterized by a contracted effective arterial blood volume resulting from renal salt wasting. Making an accurate diagnosis is important because the treatment of each condition is quite different. Vigorous salt replacement is required in patients with $\mathrm{CSW}$, whereas fluid restriction is the treatment of choice in patients with SIADH. ${ }^{18}$ The aetiology could not be assessed in our study which is an important limitation of this study.

Patients with bacterial and tubercular meningitis are at increased risk of developing acute hyponatraemia which can affect their outcome and management. Knowledge of this association will make treating clinicians be aware of the range of severity of hyponatraemia in such conditions. Knowing about the pattern and severity of hyponatraemia in meningitis can influence its treatment strategy and help thereby to curb its unfavorable outcome. Finally the study demands further research in this ground with large sample size.

\section{Conflict of Interest: None}

\section{References:}

1. Roos KL, Tyler KL. Meningitis, Encephalitis, Brain abscess and Empyema In: Harrison TR, Resnick WR, Wintrobe MM, eds. Harrisons principles of internal medicine. 17th ed. Newyork: Mcgraw-Hill 2008: 2621.

2. Allen CMC, Luek CJ, Dennis M. Neurological disease In: Boon NA, Colledge NR, Walker BR, eds. Davidsons principles $\&$ practice of medicine. 20th ed. Edinburgh: churchill livingstone 2006: 22 -50.

3. Brouwer MC, Van de Beek D, Heckenberg SGB, Spanjaard L, de Gans J. Hyponatraemia in Adults with CommunityAcquired Bacterial Meningitis. QJM 2007; 100(1): 37-40.

4. Brouwer MC, van de Beek D, de Gans J, Tunkel AR, Wijdicks EFM. Current concepts: Community- Acquired Bacterial Meningitis in Adults. N Eng J Med 2006; 354(1): 44-53.

5. Narotam PK, Kemp M, Buck R, Gouws E, van Dellen JR, Bhoola KD. Hyponatremic natriuretic syndrome in
Tuberculous Meningitis: the probable role of atrial natriuretic peptide. Neurosurgery 1994; 34: 982-988.

6. Hosoglu S, Geyik MF, Balik I. Tuberculous Meningitis in Adults in Turkey: epidemiology, diagnosis, clinic and laboratory. Eur J Epidemiol 2003; 18: 337-343.

7. Hill AR, Uribarri J, Mann J, Berl T. Altered water metabolism in Tuberculosis: role of vasopressin. Am J Med 1990; 88: 357-364.

8. Thomas E, Andreoli, eds. Cecils essential of medicine. $6^{\text {th }}$ ed. Newyork: Saunders 2006: 844-857.

9. Diringer M, Ladenson PW, Borel C, Hart GK, Kirsch JR, Hanley DF. Sodium and water regulation in a patient with cerebral salt wasting. Arch Neurol 1989; 46: 928-930.

10. Durand ML, Calderwood SB, Weber DJ, et al. Acute bacterial meningitis in adults. A review of 493 episodes. N Engl J Med 1993; 328:21.

11. Van de Beek D. Clinical features and prognostic factors in Adults with Bacterial Meningitis. N Eng J Med 2004; 351:1849-59.

12. Rapoport S, West CD, Brodsky WA. Salt losing conditions: the renal defect in tuberculous meningitis. J Lab Clin Med 1951; 550-561.

13. Singh BS, Patowari AK, Momoroma D.Serum sodium and osmolal changes in tubercular meningitis. Indian Pediatr 1994; 31(11): 1345-50.

14. Oates-Whitehead RM, Maconochie I, Baumer H, Stewart ME. Fluid therapy for acute bacterial meningitis. Cochrane Database Syst Rev 2005; 3: 4786.

15. Celik US, Alable ZD, Alhan E, Ulutan S. Cerebral salt wasting in tubercular meningitis; treatment with fludrocortisone. Am Trop paediatr 2005; 25: 297-302.

16. Kroll M, Juhler M, Lindholm J. Hyponatraemia in acute brain disease. J Intern Med 1992; 232: 291-297.

17. Laurent C, Nadia V, José LLZ, Edward B, Eric C, Gilbert D, Hassane I. Hyponatraemic syndrome in a patient with tuberculosis-always the adrenals? Nephrology Dialysis Transplantation 2008; 23(1): 393-395.

18. Peters J, Welt LG, Sims EAH, et al. Hyponatraemia in patients with central nervous system disease: SIADH versus CSW. Review trends in Endocrinology \& Metabolism 2003; 14(4): 182-187. 